\title{
Assessment of Lung Functions in Obese Young Adolescent Medical Students
}

\author{
Dr. P. Satyanarayana ${ }^{1}$,Dr. Mousomi Roy ${ }^{2}$ Dr. ChintansinghParmar ${ }^{3}$, \\ Dr.Mounika vadithya ${ }^{4}$, Dr.Srikanth ravuri ${ }^{4}$, C. Manaswi ${ }^{5}$, P. Srishti Dravid ${ }^{5}$. \\ ${ }^{1-}$ Professor \& HOD, Department of Physiology, Konaseema Institute of Medical Sciences, Amalapuram, East \\ Godavari Dist, A.P, India. \\ 2. Post graduate, Department of Physiology, Konaseema Institute of Medical Sciences, Amalapuram, East \\ Godavari Dist, A.P, India. \\ 3. Assistant Professor, Department of Physiology, Konaseema Institute of Medical Sciences, Amalapuram, \\ East Godavari Dist, A.P, India. \\ ${ }^{4}$ Post graduate, Department of Pulmonary Medicine, Konaseema Institute of Medical Sciences, Amalapuram, \\ East Godavari Dist, A.P, India. \\ 5. Medico, Department of Medicine, Konaseema Institute of Medical Sciences, Amalapuram, East Godavari \\ Dist, A.P, India.
}

\begin{abstract}
:
Background: Obesity is rapidly increasing in India in all age groups. College-based data indicates prevalence rate $24 \%$ in adolescents. Adolescent obesity is associated with a greater long-term risk of hypertension and type 2 diabetes mellitus in adulthood. However studies investigating lung functions in obese adolescents are few. The present study assesses lung functions in obese adolescent, first year medical students of KIMS medical students, Amalapuram, EG dist, Andhra Pradesh. Aims: Assessment of lung functions in obese adolescent medical students. Materials and Methods: Lung functions were measured in 67 overweight or obese adolescent medical students and an equal number of age-matched controls by using MEDI: SPIROWIN software (Maestros Medline Systems Ltd., Navi Mumbai, India). RESULTS: Forced expiratory volume in 1st second (FEV1) and forced vital capacity $(F V C)$ were significantly decreased in the overweight and obese group $(P<0.001)$. Pulmonary functions in the study population negatively correlated with obesity, weight, body mass index (BMI), The strongest negative correlation was between BMI and FVC, FEVI and FEV $/ F V C \%(P<0.001)$. Conclusion: Lung function impairment particularly decreased FVC and FEVI is associated with obesity in adolescents. In addition lung functions deteriorate with increasing obesity in adolescents. This study reveals another health hazard associated with obesity and highlights the need to reduce weight at a younger age.
\end{abstract}

Keywords: Adolescent obesity, body mass index, lung function tests (FVC, FEVI).

\section{Introduction:}

Obesity is rapidly increasing universal problem in all age groups. In United States approximately $60 \%$ of adults and one in four adolescents are overweight or obese [1], [2]. More studies are necessary to ascertain the prevalence of overweight and obesity in India. College-based data indicate a prevalence of $24 \%$ of adolescents is obese [3], [4], [5].

The causes of adolescent obesity are lack of regular exercise, sedentary habits, overconsumption of high-calorie foods, and genetic factors [6]. 80\% of adolescent obese become obese adults. Adolescent obesity is associated with a greater long-term risk of cardiovascular disease and type-2 diabetes mellitus in adulthood. In addition orthopedic issues such as slipped capital femoral epiphysis and gastrointestinal complications like cholelithiasis are more common in the obese adolescent [7]. Impairment of long functions is associated with adolescent obesity. Studies have revealed a significant reduction in forced vital capacity (FVC), forced expiratory volume in $1^{\text {st }}$ second (FEV1), and $\mathrm{FEV}_{1} / \mathrm{FVC} \%$ [8]. Significant decrease in FVC, FEV1 has been found in obese adolescents [9],[10].

Hence the present study was aimed to investigate lung function variables in the adolescent obese in first year medical students of KIMS medical students, Amalapuram, EG dist., Andhra Pradesh.

\section{Materials And Methods:}

42 overweight 25 obese and 67 normal medical students are selected as subjects from KIMS medical college Amalapuram, EG dist., Andhra Pradesh. Medical students in the age group of 17-20 years were screened to identify the overweight obese and normal weight by recording their weight (in kilograms) and height (in 
centimeters). These students came from different parts of the state. These students represents from urban, rural, tribal areas. All students are having different economic, social, cultural background.

The study protocol was ethically approved by the institutional ethical committee. All subjects were explained about the procedures to be undertaken. An informed consent of the subjects was taken on approved proforma. BMI was calculated from weight (kilograms) divided by height (square meters) by Quetelet index [10]. According to BMI all the students are classified as Normal weight (BMI-18.50 - 24.99), Overweight (BMI-25.0 - 29.99), Obese (BMI- more than 30.0), [13]. Students with symptoms of illness like fever, cough, and abdominal pain, anxious, apprehensive, and uncooperative were excluded from this study. A detailed personal history was taken about the habits like watching television, daily physical activity, diet, etc. A complete physical examination and Systemic examination was carried out by medical specialist. Pulse and blood pressure were recorded.

PULMONARY FUNCTION TESTING: The subjects were demonstrated the maneuvers of the lung function tests. Computerized spirometry was carried out using MEDI: SPIROWIN software (Maestros Medline Systems Ltd., Navi Mumbai, India). [13] with the subject sitting position. For the FVC maneuver subjects were asked to take deep inspiration and breathe out as rapidly as and as long as possible into the mouth of the spirometer. Flow volume curve was plotted. Best of three acceptable maneuvers being taken as the final reading. FVC, FEV1, FEV1/FVC\%, was taken as lung function tests for our study.

\section{Results:}

Table 1

Comparison between normal weight $(n=42)$ \& overweight $(n=42)$

\begin{tabular}{|c|c|c|c|}
\hline Parameters & $\begin{array}{c}\text { Mean+ SD (n=42) } \\
\text { (Normal Weight) }\end{array}$ & $\begin{array}{c}\text { Mean + SD (n=42) } \\
\text { (Over weight) }\end{array}$ & p value \\
\hline BMI & $21.65+1.83$ & $27.52+1.51$ & $\mathrm{P}<0.001$ \\
\hline Body fat $\%$ & $20.50+8.20$ & $31.08+8.81$ & $\mathrm{P}<0.001$ \\
\hline FVC & $2.90+0.85$ & $2.72+0.52$ & $\mathrm{P}<0.001$ \\
\hline FEV & $4.14+11.90$ & $2.56+0.44$ & $\mathrm{P}<0.001$ \\
\hline $\mathrm{FEV}_{1} / \mathrm{FVC} \%$ & $93.27+13.52$ & $94.74+6$ & $\mathrm{P}<0.001$ \\
\hline
\end{tabular}

Table 1. BMI of Overweight group and Normal Weight group are $27.52+1.51$ and $21.65+1.83$ respectively. There is significant increase of BMI in over weight group than Normal Weight group. $\mathrm{p}$ value is $\mathrm{P}$ $<0.001$. Body fat percentage of Overweight group and Normal Weight group is $31.08+8.81$ and $20.50+8.20$ respectively. There is significant rise of Body fat percentage in over weight group than Normal Weight group. $p$ value is $\mathrm{P}<0.001$. FVC of Overweight group and Normal Weight group are $2.72+0.52$ and $2.90+0.85$ respectively. Significant Decrease of FVC in over weight group than Normal Weight group. p value is P < 0.001 . FEV1 of Overweight group and Normal Weight group are $2.56+0.44$ and $4.14+11.90$ respectively. Significant Decrease of FEV1 in over weight group than Normal Weight group. p value is $\mathrm{P}<0.001$. FEV1/FVC percentage of Overweight group and Normal Weight group are $94.74+6$ and $93.27+13.52$ respectively. No significant changes of FEV1/FVC percentage in over weight group than Normal Weight group. $\mathrm{p}$ value is $\mathrm{P}<0.001$.

Table 2.

Comparison between normal weight $(n=25)$ \& obese group $(n=25)$.

\begin{tabular}{|c|c|c|c|}
\hline Parameters & $\begin{array}{c}\text { Mean+ SD (n=25) } \\
\text { (Normal Weight) }\end{array}$ & $\begin{array}{c}\text { Mean + SD (n=25) } \\
\text { (Obese) }\end{array}$ & p value \\
\hline BMI & $21.65+1.83$ & $32.70+3.78$ & $\mathrm{P}<0.001$ \\
\hline Body fat \% & $20.50+8.20$ & $40.18+8.60$ & $\mathrm{P}<0.001$ \\
\hline FVC & $2.90+0.85$ & $2.61+0.50$ & $\mathrm{P}<0.001$ \\
\hline FEV1 & $4.14+11.90$ & $2.52+0.44$ & $\mathrm{P}<0.001$ \\
\hline FEV1/FVC $\%$ & $93.27+13.52$ & $96.85+4.25$ & $\mathrm{P}<0.001$ \\
\hline
\end{tabular}

Table 2. BMI of Obese group and Normal Weight group are $32.70+3.78$ and $21.65+1.83$ respectively. There is significant increase of BMI in Obese group than Normal Weight group. $\mathrm{p}$ value is $\mathrm{P}<$ 0.001. Body fat percentage of obese group and Normal Weight group are $40.18+8.60$ and $20.50+8.20$ respectively. There is significant rise of Body fat percentage in obese group than Normal Weight group. p value is $\mathrm{P}<0.001$. FVC of Obese group and Normal Weight group are $2.61+0.50$ and $2.90+0.85$ respectively. Significant Decrease of FVC in Obese group than Normal Weight group. $\mathrm{p}$ value is $\mathrm{P}<0.001$.

FEV1 of Obese group and Normal Weight group are $2.52+0.44$ and $4.14+11.90$ respectively. Significant Decrease of FEV1 in Obese group than Normal Weight group. p value is $\mathrm{P}<0.001$. FEV1/FVC percentages of 
obese group and Normal Weight group are96.85 + 4.25and 93.27 + 13.52 respectively. No significant changes of FEV1/FVC percentage in Obese group than Normal Weight group. p value is $\mathrm{P}<0.001$.

Table 3 .

Actual \& predicted values in Over weight and obese group.

\begin{tabular}{|c|c|c|c|c|c|c|c|c|}
\hline \multirow{2}{*}{ Parameters } & \multicolumn{4}{|c|}{ Over weight } & \multicolumn{4}{|c|}{ Obese subjects. } \\
\hline & $\begin{array}{l}\text { Actual } \\
\text { values }\end{array}$ & $\begin{array}{l}\text { predicted } \\
\text { values }\end{array}$ & P Value. & Significance & $\begin{array}{l}\text { Actual } \\
\text { values }\end{array}$ & $\begin{array}{l}\text { predicted } \\
\text { values }\end{array}$ & P Value. & Significance \\
\hline FVC & $2.72+0.52$ & $\begin{array}{l}3.08 \\
0.56\end{array}$ & 0.02 . & Significant & $\begin{array}{c}2.61+ \\
0.50\end{array}$ & $\begin{array}{l}3.08 \\
0.56\end{array}$ & 0.0031 & Significant \\
\hline FEV1 & $2.56+0.44$ & $\begin{array}{l}2.70 \\
0.45\end{array}$ & 0.07 . & Significant & $\begin{array}{c}2.52+ \\
0.44\end{array}$ & $\begin{array}{l}2.71 \\
0.40\end{array}$ & 0.06 . & Significant \\
\hline FEV1/FVC \% & $94.74+6$ & $\begin{array}{ll}84.82 & + \\
0.84 & \end{array}$ & $<0.0001$ & Significant & $\begin{array}{l}96.85+ \\
4.25\end{array}$ & $\begin{array}{l}85.28 \\
0.74 \\
\end{array}$ & $<0.0001$ & Significant \\
\hline
\end{tabular}

Table 3.

Actual value of FVC in overweight subjects $2.72+0.52$ and in obese subjects $2.61+0.50$. Predicted value of FVC in overweight subjects $3.08+0.56$ and in obese subjects $3.08+0.56$. Actual value of FVC is significantly less than predicted value of FVC in both overweight and obese groups. Actual value of FEV1 in overweight subjects $2.56+0.44$ and in obese subjects $2.52+0.44$.Predicted value of FEV1 in overweight subjects $2.70+0.45$ and in obese subjects $2.71+0.40$. Actual value of FEV1 is significantly less than predicted value of FEV1 in both overweight and obese groups. Actual value of FEV1/FVC \% in overweight subjects $94.74+6$ and in obese subjects $96.85+4.25$. Predicted value of FEV1/FVC \% in overweight subjects $84.82+$ 0.84 and in obese subjects $96.85+4.25$. Actual value of FEV1/FVC \% is significantly more than predicted value of FEV1/FVC \% in both overweight and obese groups.

\section{Discussion:}

In our study a predominant reduction in the FVC, FEV1, was observed in the obese and overweight subjects than the normal subjects. A decrease in the FVC, FEV1was also observed by Inselman et al [15] and Mallory et al [16]. However, no significant reduction was detected by Bossisio et al [17] and Chaussain et al [18].A reduction in the absolute value of FEV1 indicates airway narrowing [19].But no obstructive impairment was detected in any of the obese and overweight subjects and results are indicative of airflow limitation without significant obstruction.

In our study among normal weight, overweight and obese medical students, FVC and FEV1 were strongly negatively correlated with body weight and BMI. This suggests that lung function may be impaired though not sufficiently to cause clinical abnormality. The strongest negative correlation between BMI and pulmonary function was observed by Sri Nageswari et al [11].They hypothesized that obesity is characterized by decrease in chest wall compliance due to increased amount of adipose tissue around the chest and abdomen which decreases pulmonary functions in these medical students.

A number of hypotheses have been proposed to explain the negative correlation between lung function parameters and BMI. One possible mechanism is a mechanical limitation of chest expansion during the FVC maneuver. Increased abdominal mass may impede the descent of the diaphragm and increase the thoracic pressure. In addition visceral adipose tissue influences circulating concentrations of interleukin-6, tumor necrosis factor-alpha, leptin, and adiponectin, which are cytokines that may act via systemic inflammation to negatively affect pulmonary function [23], [24], [25], [26].Many authors reported an inverse association of serum leptin concentrations with FEV1. Higher levels of C-reactive protein, leukocytes, and fibrinogen, which are markers of systemic inflammation, may be the link between visceral obesity and pulmonary function [27].

\section{Conclusion:}

Lung functions are decreased in overweight and obese adolescent medical students as compared to normal weight subjects. However no clinical abnormality like obstructive or restrictive diseases has been detected in any of these overweight and obese medical students.

\section{Acknowledgement}

I am very much thankful to our $13-14^{\text {th }}$ year batch medical students and KIMS management for their cooperation for performing this research work. Financial help was not taken from any funding agencies. 


\section{References}

[1]. World Health Organization. Obesity: Preventing and managing the global epidemic. Geneva, Switzerland: World Health Organization; 1997.

[2]. Dietz WH. Health consequences of obesity in youth: Childhood predictors of adult disease. Pediatrics 1998; 101:518-25.

[3]. Yadav S. Obesity: An increasing problem in the developing countries. Indian Journal of Practical Pediatrics 2001; 4:293-7.

[4]. Kapil U, Singh P, Pathak P, Dwivedi N, Bhasin S. Prevalence of obesity amongst affluent schoolchildren in Delhi. Indian Pediatr 2002; 39:449-52

[5]. Bhave S, Bavdekar A, Otiv M. IAP national task force for childhood prevention of adult diseases: Childhood obesity. Indian Pediatr 2004; 41:559-75.

[6]. Ebbeling CB, Pawlak DB, Ludwig DS. Childhood obesity: Public health crisis, common sense cure. Lancet 2002; 360:473-82.

[7]. Michael Brown W, Sibille K, Phelps L, Mcfarlanne KJ. Obesity in children and adolescents. Clinics in Family Practice 2002; 4:60321.

[8]. Biring MS, Lewis MI, Liu JT, Mohsenifar Z. Pulmonary physiologic changes of morbid obesity. Am J Med Sci 1999; 318:293-7.

[9]. Li A, Chan D, Wong E, Yin J, Nelson E, Fok T. The effects of obesity on pulmonary function. Arch Dis Child 2003; 88:361-3.

[10]. Ho TF, Tay JS, Yip WC, Rajan U. Evaluation of lung function in Singapore obese children. J Singapore PaediatrSoc 1989; 31:4652.

[11]. Sri Nageshwari K, Sharma R, Kohli DR. Assessment of respiratory and sympathetic cardiovascular parameters in obese school children. Indian JPhysiolPharmacol2007; 51:235-43.

[12]. Cole TJ, Bellini MC, Flegal KM, Dietz WH. Establishing a standard definition for child overweight and obesity worldwide: International survey.BMJ,2000;320:1240-6.

[13]. Miller MR, Hankinson J, Brusasco V, Burgos F, Casaburi R, Coates A, et al. Series "ATS/ ERS task force: Standardization of lung function testing". Eur, Respir, J2005; 26:319-38.

[14]. Pauwels RA, Buist AS, Ma P, Jenkins CR, Hurd SS. Global strategy for the diagnosis, prevention and management of chronic obstructive pulmonary disease. National Heart, Lung, and Blood Institute and World Health Organization Global initiative for Obstructive Lung Disease (GOLD): Executive summary. Respir Care 2001; 46:798-825.

[15]. Inselman LS, Milanese A, Deurloo A. Effect of obesity on pulmonary function in children. PediatrPulmonol 1993; 16:130-7.

[16]. Mallory GB, Fiser DH, Jackson R. Sleep associated breathing disorders in morbidly obese children and adolescents. J Pediatr 1989; 115:892-7

[17]. Bossisio E, Sergi M, Di Natale B. Ventilatory volumes, flow rates, transfer factor and its components (membrane component, capillary volume ) in obese adults and children. Respiration 1984; 45:321-6.

[18]. Chausssain M, Gamain B, La Torre AM. Respiratory functions at rest in obese children. Bull EurPhysiopatholRespir 1977; 13:599609.

[19]. Seaton A, Seaton D, Gordon Leitch A. Crofton and Douglas's respiratory diseases. 5 th ed. Vol.1. Oxford: Blackwell Sciences Ltd.; 2000. p 63.

[20]. Ochs-Balcom HM, Grant BJ, Muti P, Sempos CT, Freudenheim JL, Trevisan M, et al. Pulmonary function and abdominal adiposity in the general population. Chest 2006; 129:853-62.

[21]. Harik-Khan RI, Wise RA, Fleg JL. The effect of gender on the relationship between body fat distribution and pulmonary function. J ClinEpidemiol 2001; 54:399-406.

[22]. Lazarus R, Sparrow D, Weiss ST. Effects of obesity and fat distribution on ventilatory function: The normative aging study. Chest 1997; 111:891-8.

[23]. Kern PA, Rangnathan S, Li C, Wood L, Rangnathan G. Adipose tissue tumor necrosis factor and interleukin-6 expression in human obesity and insulin resistance. Am J PhysiolEndocrinolMetab 2001; 280:E745-51.

[24]. Staiger H, Tschritter O, Machann J, Thamer C, Fristsche A, Maerker E, et al. Relationship of serum adiponectin and leptin concentrations with body fat distribution in humans. Obes Res 2003; 11:268-72.

[25]. Gasteyer C, Tremblay A. Metabolic impact of body fat distribution. J Endocrinol Invest 2002; 25:876-83

[26]. Kern PA, DiGregorio GB, Lu T, Rassouli N, Ranganathan G. Adiponectin expression from human adipose tissue: Relation to obesity, insulin resistance, and tumor necrosis factor-alpha expression. Diabetes 2003; 52:1779-85.

[27]. Sin DD, Man SF. Impaired lung function and serum leptin in men and women with normal body weight: A population based study. Thorax 2003; 58:695-8. 